\title{
JUURNAL_RU
}

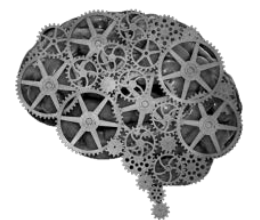

COMPANY GROUP "INTELLEKT"

\author{
Стельмах В.Ю. \\ Уральский юридический институт МВД России \\ Екатеринбург, Россия
}

doi: 10.18411/lj2016-6-4-07

\section{Процессуальные особенности задержания в качестве подозреваемого и избрания меры пресечения в отношении несовершеннолетнего}

В соответствии с п. b ст. 37 Конвенции о правах ребенка [1], арест, задержание или тюремное заключение ребенка (то есть лица, не достигшего 18 лет) осуществляются согласно закону и используются лишь в качестве крайней меры и в течение как можно более короткого соответствующего периода времени. Эти правила учтены в действующем УПК РФ [2].

Задержание несовершеннолетнего по подозрению в совершении преступления осуществляется по общим правилам, сформулированным в ст.ст. 91 и 92 УПК РФ (ч. 1 ст. 423 УПК РФ). О задержании несовершеннолетнего должен быть немедленно уведомлен его законный представитель (ч. 3 ст. 423 УПК РФ), при этом, если в случае задержания взрослого лица возможно принять решение о сохранении факта задержания в тайне с согласия надзирающего прокурора, то в отношении несовершеннолетних это не допускается (ч. 4 ст. 96 УПК РФ).

Для несовершеннолетних существует специальная мера пресечения отдача под присмотр (ст. 105 УПК РФ). При решении вопроса об избрании меры пресечения к несовершеннолетнему подозреваемому, обвиняемому в каждом случае должна обсуждаться возможность применения именно этой меры пресечения (ч. 2 ст. 423 УПК РФ, п. 7 постановления Пленума Верховного Суда РФ от 1 февраля 2011 года № 1 [3]). 
По смыслу закона, иная мера пресечения к несовершеннолетнему может быть избрана только в случае невозможности отдачи под присмотр, причем эта невозможность должна быть мотивирована в постановлении следователя (дознавателя).

Осуществление присмотра поручается субъектам, указанным в ч. 1 ст. 105 УПК РФ:

родителям;

опекунам;

попечителям;

другими заслуживающим доверия лицам;

должностным лицам специализированного детского учреждения, в котором находится несовершеннолетний.

К родителям относятся родители по происхождению (кроме случаев, когда они лишены родительских прав), а также усыновители (ч. 1 ст. 137 СК РФ [4]).

Опекуны и попечители. Опека назначается в отношении лиц, не достигших 14 лет, а попечительство - в отношении лиц в возрасте от 14 до 18 лет (п.п. 1 и 2 ст. 2 Федерального закона «Об опеке и попечительстве» [5], ч. 2 ст. 145 СК РФ). Таким образом, с учетом того, что возраст привлечения к уголовной ответственности не может быть менее 14 лет, несовершеннолетний подозреваемый или обвиняемый может быть отдан под присмотр только попечителям.

Опекуны и попечители назначаются органами опеки и попечительства (ч. 2 ст. 11 Федерального закона «Об опеке и попечительстве»).

Другие заслуживающие доверия лица. Какого-либо нормативного перечня данных лиц законодательство не устанавливает, очевидно, что к ним могут относиться любые физические лица, не обязательно находящиеся в родственных отношениях с несовершеннолетним, по аналогии с теми, которые могут выступать личными поручителями. Хотя в законе это прямо не указано, думается, что данное лицо должно быть совершеннолетним. 
Должностные лица специализированного детского учреждения, в котором находится несовершеннолетний. Специализированные учреждения для несовершеннолетних перечислены в ч. 1 ст. 13 и ст. 15 Федерального закона «Об основах системы профилактики безнадзорности и правонарушений несовершеннолетних» [6]:

1) социально-реабилитационные центры;

2) социальные приюты;

3) центры помощи детям, оставшимся без попечения родителей;

4) специальные учебно-воспитательные учреждения открытого типа;

5) специальные учебно-воспитательные учреждения закрытого типа.

Лицам, которым несовершеннолетний отдается под присмотр, следователь или дознаватель должны разъяснить существо подозрения или обвинения, а также их ответственность, связанную с обязанностями по присмотру (ч. 2 ст. 105 УПК РФ).

Процессуальный порядок избрания меры пресечения в виде отдачи несовершеннолетнего под присмотр включает в себя 3 этапа:

1) Вынесение следователем (дознавателем) постановления об избрании меры пресечения. В описательно-мотивировочной части постановления отмечается, что подозреваемый или обвиняемый является несовершеннолетним, и мотивируется возможность его отдачи под присмотр соответствующему лиц.

2) Ознакомление обвиняемого (подозреваемого), его защитника, а также лица, которому несовершеннолетний отдается под присмотр, с данным постановлением. Все указанные лица делают отметку об ознакомлении на постановлении.

3) Составление лицом, которому несовершеннолетний отдается под присмотр, соответствующей подписки, в которой указываются его обязанности и ответственность за невыполнение обязательства денежное взыскание в размере до 10.000 рублей (ч. 3 ст. 105 УПК РФ). 
В случае избрания в качестве меры пресечения присмотра родителей (а также любой другой, не связанной с заключением подозреваемого или обвиняемого под стражу), дознаватель обязан отправить документы, предусмотренные ведомственными нормативными актами, направленные на воспрепятствование уклонения обвиняемого (подозреваемого) от предварительного расследования:

a) в течение 3 суток с момента избрания меры пресечения дознавателем должна быть в письменном виде направлена информация в орган внутренних дел по месту жительства и проживания подозреваемого или обвиняемого с указанием полных анкетных данных лица, его процессуального статуса, квалификации инкриминируемого ему деяния, даты избрания меры пресечения;

б) письменные уведомления («сторожевые листки»): в отдел ФМС по месту регистрации обвиняемого; в областное адресно-справочное бюро (ОАСБ);

в Управление МВД на транспорте (УТ) для отслеживания перемещений обвиняемого с помощью системы «Магистраль»;

в военный комиссариат по месту нахождения обвиняемого на воинском учете;

в отдел кадров по месту работы (учебы) обвиняемого.

Такая мера пресечения, как заключение под стражу, к несовершеннолетнему может быть применена только в тех случаях, когда он подозревается или обвиняется в совершении тяжкого или особо тяжкого преступления, а в исключительных случаях - в совершении преступления средней тяжести (ч. 2 ст. 108 УПК РФ). Заключение под стражу до судебного разбирательства может применяться к несовершеннолетнему лишь в качестве крайней меры и в течение кратчайшего периода времени. Суд обязан проверить обоснованность доводов следователя (дознавателя) о необходимости избрания меры пресечения (абз. 1 п. 6 постановления Пленума Верховного Суда РФ от 1 
февраля 2011 года № 1).

Кроме того, мера пресечения в виде заключения под стражу, по общему правилу, может быть применена только за совершение тех преступление, по которым санкция статьи УК РФ [7] предусматривает наказание не менее 3 лет лишения свободы. При избрании меры пресечения в виде заключения под стражу в отношении несовершеннолетних необходимо учитывать, что максимальный размер наказания в виде лишения свободы, которое может быть назначено несовершеннолетнему, составляет 10 лет, при этом лицам в возрасте от 14 до 16 лет наказание свыше 6 лет может быть назначено только за совершение особо тяжкого преступления (ч. 6 ст. 88 УК РФ).

По смыслу закона, избрание меры пресечения в виде заключения под стражу не допускается в отношении несовершеннолетних:

а) не достигших 16 лет, подозреваемых или обвиняемых в совершении преступлений небольшой или средней тяжести впервые;

б) в возрасте от 16 до 18 лет, совершивших преступления небольшой тяжести впервые (абз. 2 п. 6 постановления Пленума Верховного Суда РФ от 1 февраля 2011 года № 1).

Данное разъяснение Пленума Верховного Суда Российской Федерации основано на том, что в указанных случаях несовершеннолетним не может быть назначено наказание в виде лишения свободы. Следовательно, констатирует Пленум Верховного Суда, такое наказание именно для данной категории лиц как бы не предусмотрено в санкции соответствующей статьи УК РФ.

В случае избрания в отношении несовершеннолетнего меры пресечения в виде заключения под стражу, а также продления срока содержания под стражей об этом незамедлительно извещаются его законные представители (ч. 3 ст. 423 УПК РФ).

Таким образом, установленный в Российской Федерации процессуальный порядок задержания несовершеннолетнего в качестве подозреваемого и избрания в отношении него меры пресечения соответствует мировым 
стандартам, позволяет эффективно произвести расследование и при этом обеспечить права и законные интересы несовершеннолетнего. 


\section{Литература:}

1. Конвенция о правах ребенка. Принята резолюцией 44/25 Генеральной Ассамблеи ООН от 20 ноября 1989 года. [Электронный ресурс]. http://www.un.org/ru/documents/decl_conv/conventions/childcon (дата обращения: 05.06.2016 г.).

2. Уголовно-процессуальный кодекс Российской Федерации: Федеральный закон от 18 декабря 2001 года № 174-ФЗ (ред. от 1 мая 2016 года) // Собрание законодательства Российской Федерации. 2001. № 52 (ч. І). Ст. 4921.

3. Постановление Пленума Верховного Суда Российской Федерации от 1 февраля 2011 года № 1 «О судебной практике применения законодательства, регламентирующего особенности уголовной ответственности и наказания несовершеннолетних» (ред. от 2 апреля 2013 года) // Бюллетень Верховного Суда Российской Федерации. 2011. № 4. С. 2-6.

4. Семейный кодекс Российской Федерации: Федеральный закон от 29 января 1995 года № 223-ФЗ (ред. от 30 декабря 2015 года) // Собрание законодательства Российской Федерации. 1996. № 1. Ст. 16.

5. Федеральный закон «Об опеке и попечительстве» от 24 апреля 2008 года № 48-Ф3 (ред. от 28 ноября 2015 года) // Собрание законодательства Российской Федерации. 2008. № 17. Ст.1755.

6. Федеральный закон «Об основах системы профилактики безнадзорности и правонарушений несовершеннолетних» от 24 июня 1999 года № 120-Ф3 (ред. от 26 апреля 2016 года) // Собрание законодательства Российской Федерации. 1999. № 26. Ст. 3177.

7. Уголовный кодекс Российской Федерации: Федеральный закон от 13 июня 1996 года № 63-Ф3 (ред. от 1 мая 2016 года) // Собрание законодательства Российской Федерации. 1996. № 25. Ст. 2954. 